
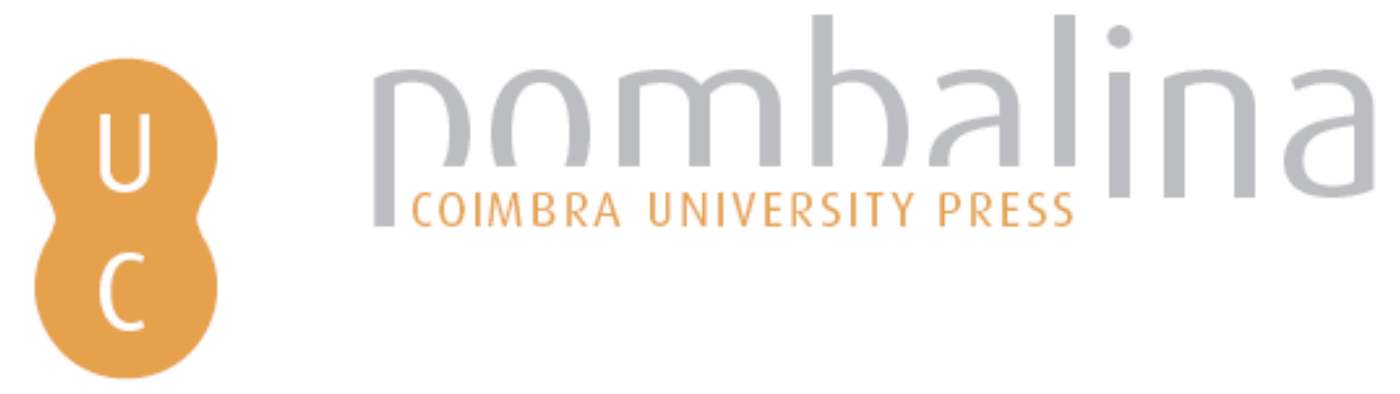

\title{
Time perspective orientation and big-five dimensions: an exploratory study in the portuguese population
}

Autor(es): $\quad$ Figueira, Pedro; Bártolo-Ribeiro, Rui

Publicado por: Imprensa da Universidade de Coimbra

URL

persistente: URI:http://hdl.handle.net/10316.2/38613

DOI: $\quad$ DOI:http://dx.doi.org/10.14195/978-989-26-0775-7_9

Accessed : $\quad$ 26-Apr-2023 15:44:38

A navegação consulta e descarregamento dos títulos inseridos nas Bibliotecas Digitais UC Digitalis, UC Pombalina e UC Impactum, pressupõem a aceitação plena e sem reservas dos Termos e Condições de Uso destas Bibliotecas Digitais, disponíveis em https://digitalis.uc.pt/pt-pt/termos.

Conforme exposto nos referidos Termos e Condições de Uso, o descarregamento de títulos de acesso restrito requer uma licença válida de autorização devendo o utilizador aceder ao(s) documento(s) a partir de um endereço de IP da instituição detentora da supramencionada licença.

Ao utilizador é apenas permitido o descarregamento para uso pessoal, pelo que o emprego do(s) título(s) descarregado(s) para outro fim, designadamente comercial, carece de autorização do respetivo autor ou editor da obra.

Na medida em que todas as obras da UC Digitalis se encontram protegidas pelo Código do Direito de Autor e Direitos Conexos e demais legislação aplicável, toda a cópia, parcial ou total, deste documento, nos casos em que é legalmente admitida, deverá conter ou fazer-se acompanhar por este aviso.

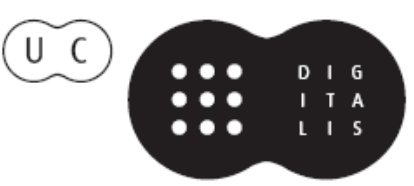




\section{INTERNATIONAL \\ STUDIES IN TIME \\ PERSPECTIVE}

MARIA PAULA PAIXÃO

JOSÉ TOMÁS DA SILVA

(COORD.)

VICTOR ORTUÑO

PEDRO CORDEIRO

(EDITORS)

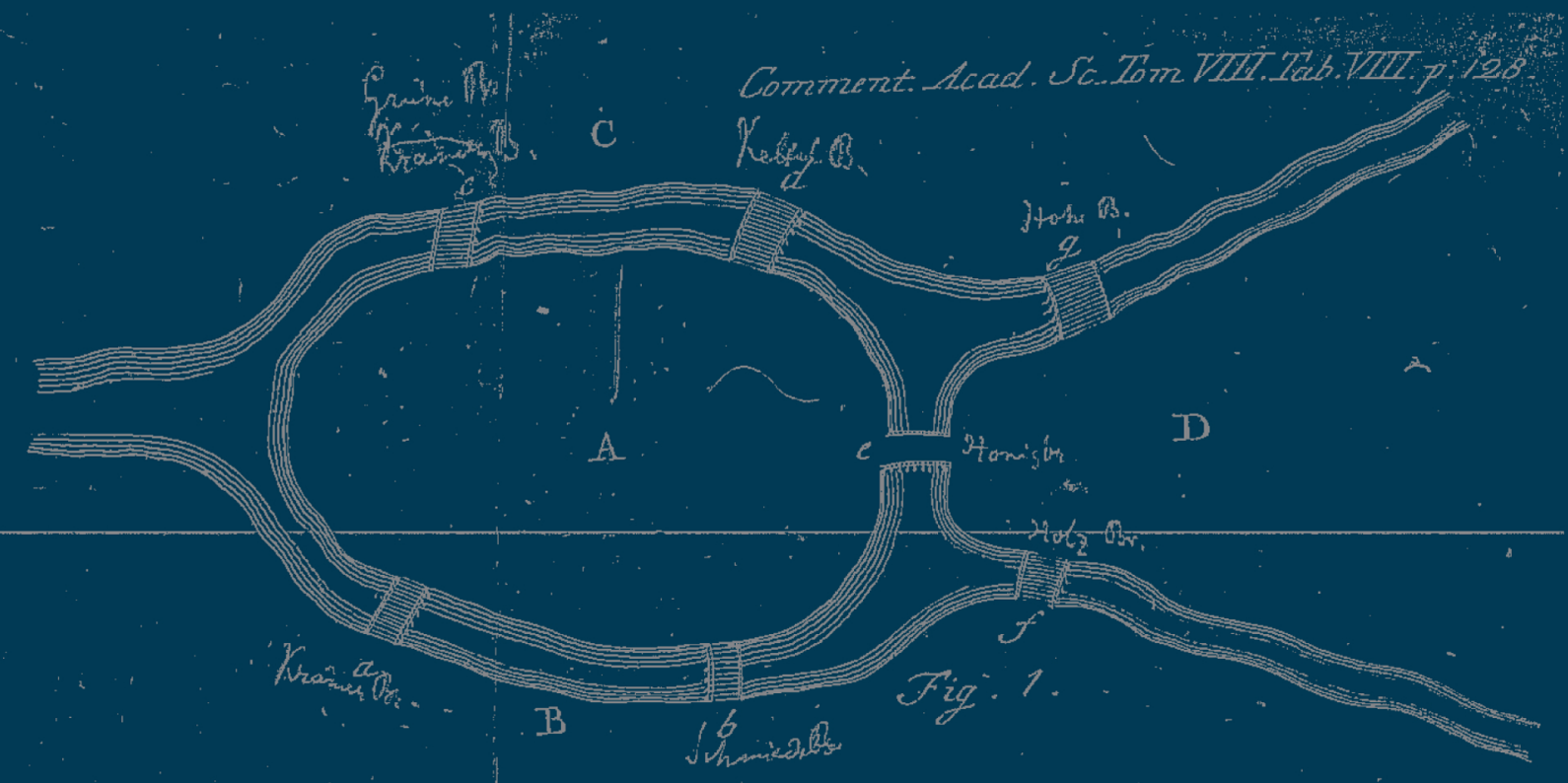

IMPRENSA DA

UNIVERSIDADE

DE COIMBRA

COIMBRA

UNIVERSITY

PRESS 
Chapter 9

Time Perspective orientation and Big-Five dimensions: An eXPloratory study in the Portuguese population

\author{
Pedro Figueira \\ Rui Bártolo-Ribeiro \\ ISPA - University Institute / CAP, Portugal \\ pfigueira@ispa.pt \\ rbartolo@ispa.pt
}

Aвstract: Zimbardo and Boyd (1999), with their Time Perspective scale, have shown relations between the time perspective's dimensions and Big-Five's dimensions. Recent studies (Dunkel \& Weber, 2010) show the existence of such relations. The present study used the Portuguese version of Zimbardo Time Perspective Inventory (Ortuño \& Gamboa, 2008) and the short version (10 itens) of Big Five Inventory (Rammstedt $\&$ John, 2007), adapted to Portuguese by Bártolo-Ribeiro and Aguiar (2008). Both scales were applied to 326 participants in two different application contexts (online and face-to-face). The results shows that different temporal perspectives are associated to different personality dimensions, confirming in a global way the results already found in previous studies with other personality questionnaires, namely significant correlations between negative past and neuroticism; positive past and agreeableness; hedonist present with extraversion; fatalist present with conscientiousness (negatively); and future with conscientiousness.

Keywords: time perspective, big-five, ZTPI, connection

\title{
INTRODUCTION
}

"It's all a matter of time"

We can remember our past experiences, we can think of what we are doing now, and we can imagine what we will do in the future. All of these processes leave traces in our mental organization, which may influence our personality organization.

In Zimbardo's \& Boyd's (1999) Time Perspective Theory, the time orientations (past, present and future) are viewed as a basis dimension of human functioning. In this line, it is defended that all the lived experiences by an individual are codified in specific time frames. If there were no such time frames it would be impossible for the individual to maintain an order and coherence of the events.

The importance of these time frames does not restring the codification, storage and the coherent retrieval of living experiences, but also involves the formation of expectations and objectives which influenced decisions, judgments and actions.

The balance between these time frames may be thinking as a differentiating variable between the individuals, existing certain situations in which the individual focuses more 
in information contained in the past, present or future frame. Zimbardo, Keough \& Boyd (1997) state that when this focus process is cronical in one of the time frames, it can be considered as a personality trait.

Zimbardo \& Boyd (1999) have created the Zimbardo Time Perspective Inventory (ZTPI) for theory validation. Despite their instrument had been developed for measuring 3 dimensions, they identified 5 dimensions: negative past, positive past, hedonist present, fatalist present and future. The authors also have identified relations between these dimensions and the Big-Five model dimensions (see Table 1).

Table 1 - Zimbardo \& Boyd (1999) correlations between the ZTPI dimensions and the Big-Five

\begin{tabular}{|l|l|l|}
\hline & Positive Correlation & Negative Correlation \\
\hline Negative Past & Neuroticism & $\begin{array}{l}\text { Agreeableness, Conscientiousness and } \\
\text { Extraversion }\end{array}$ \\
Hedonist Present & $\begin{array}{l}\text { Agreeableness and Extraversion } \\
\text { Extraversion and Neuroticism }\end{array}$ & $\begin{array}{l}\text { Conscientiousness } \\
\text { Fatalist Present }\end{array}$ \\
Future & $\begin{array}{l}\text { Neuroticism } \\
\text { Conscientiousness, Extraversion and } \\
\text { Openness }\end{array}$ & \\
\hline
\end{tabular}

More recently, Dunkel \& Weber (2010) have performed a correlational study between the ZTPI and the Big-Five dimensions (Table 2).

Table 2 - Dunkel \& Weber (2010) correlations between the ZTPI dimensions with the Big-Five

\begin{tabular}{|l|l|l|}
\hline & Positive Correlation & Negative Correlation \\
\hline Negative Past & Neuroticism & Openness, Agreeableness and Extraversion \\
Positive Past & $\begin{array}{l}\text { Agreeableness and Extraversion } \\
\text { Openness, Extraversion and } \\
\text { Agreeableness }\end{array}$ & Conscientiousness and Neuroticism \\
Fatalist Present & $\begin{array}{l}\text { Conscientiousness } \\
\text { Future }\end{array}$ & Neuroticism
\end{tabular}

Once again, and in comparison with the previous table, some correlations are repeated in the Zimbardo \& Boyd (1999) and Dunkel \& Weber (2010) studies. Only looking at the more significant correlations $(p<001)$ that are repeated in both studies, we observe that Negative Past relates to Neuroticism, Possitive Past relates to Agreeableness, Hedonist 
Present relates to Extroversion, Fatalist Present negatively relates to Consciousness and Future relates to Consciousness, being the Openness the only dimension of Big-Five that doesn't seem to stabilize crossing these two studies.

However, it's important to refer that this data relates to American samples which turns relevant to explore the relations of TP with the Big-Five on Portuguese population.

Despite the current study has an exploratory objective, it's not expected that the found relations between TP and Big-Five in the Portuguese population, will be much different of the ones that were found in the data crossing by Zimbardo and Boyd (1999) and Dunkel and Weber (2010).

\section{Method}

\section{Sample}

This study has counted with 326 participants (60\% male) with an age average of 29,3 years and a standard-deviation of 8,96, being the youngest participant 16 years old and the oldest 63 years old.

\section{Instruments}

The following instruments were used in order to study the relation between TP and the Big-Five model:

ZTPI (Zimbardo \& Boyd, 1999), portuguese version translated by Ortuño \& Gamboa (2008). The 56 items inventory allows to measure the fin dimensions of time perspective 5 dimensions (Negative past, Positive past, Hedonist present, Fatalist present and Future).

BFI-10 (Rammstedt \& John, 2007), an adapted version to Portuguese population by Bártolo-Ribeiro and Aguiar (2008), is a short version of 10 items of BFI-44. It measures 5 Big-Five dimensions (Openness, Agreeableness, Conscientiousness, Extraversion, and Neuroticism) in one minute or less.

\section{Procedure}

The data collection was performed in two application contexts: one in a face-to face way, using paper and pen (19,3\% of the sample) and other in an online way, using "Kwik Surveys", a platform that allows to apply questionnaires for site disclosure.

\section{Results}

To explore the relations of TP model and the Big-Five model, we performed a correlation analysis between ZTPI and the BFI-10 dimensions (Table 3). 
Table 3 - Correlations between the ZTPI and the Big-Five Dimensions

\begin{tabular}{|l|c|c|c|c|c|}
\hline & \multicolumn{5}{|c|}{ BFI-10 dimensions } \\
\hline ZTPI dimensions & Openness & Agreeableness & Conscientiousness & Extraversion & Neuroticism \\
\hline Negative Past & -.03 & $-.19^{* * *}$ & $-.25^{* * *}$ & -.07 & $.37^{* * *}$ \\
\hline Positive Past & -.02 & $.28^{* * *}$ & -.01 & $.20^{* * *}$ & -.1 \\
\hline Hedonist Present & $.22^{* * *}$ & $.16^{* *}$ & $-.16^{* *}$ & $.28^{* * *}$ & .08 \\
\hline Fatalist Present & -.13 & -.07 & $-.24^{* * *}$ & -.01 & $.15^{* *}$ \\
\hline Future & $.12^{*}$ & $.17^{* *}$ & $.44^{* * *}$ & .09 & .06 \\
\hline
\end{tabular}

$N=326 .{ }^{*} p<0,05 ;{ }^{* *}<0,01 ;{ }^{* * *} p<0,001$

Like it is suggested in Table 3, different TP's dimensions relate to different Big-Five traits. Reporting most significant correlations, Negative Past is positively correlated with Neuroticism, but negatively with Conscientiousness and Agreeableness. Positive Past is associated with Agreeableness and Extraversion. Hedonist Present is correlated with Extraversion and Openness. Fatalist Present has a negative correlation with Conscientiousness. Finally, is verified a strong and direct correlation between Future and Conscientiousness, contrary to negative relation with Negative Past.

\section{DisCUSSION AND SOME CONSIDERATIONS}

This study demonstrates that the relations between the TP and the Big-Five dimensions in a portuguese sample, at least the more significant ( $\mathrm{p}<.001)$, don't differ significantly from the studies with American samples (Zimbardo \& Boyd, 1999; Dunkel \& Weber, 2010), except the relation between Negative Past and Extroversion that may suggest the existence of cultural differences in the way that people deal or compensate their negative past experiences.

Our research also sustains the use of reduced scales (e.g. BFI-10), enhancing the idea of Robins, Tracy, Trzesniewski, Potter \& Gosling (2001), that these short versions are faster but, also, reliable measuring instruments when applied in research contexts. However, in future studies it would still be relevant to use more complete personality scales to access not only the 5 dimensions of superior order, but also its sub dimensions in order to draw a more complete personality profile.

\section{References}

Bártolo-Ribeiro, R., \& Aguiar R. (2008). Avaliação Rápida da Personalidade: Estudo Preliminar da Versão Portuguesa Reduzida de 10 itens do Big Five Inventory (A quick personality measuring: A first study of the short Portuguese version of 10-item Big Five Inventory). In Actas do XIII Congresso Internacional de Avaliação Psicológica: Formas e Contexto. Braga (Portugal): Universidade do Minho 2 a 4 de Outubro. Braga: Psiquilíbrios Edições. 
Dunkel, C. S., \& Weber, J. L. (2010). Using three levels of personality to predict time perspective. Current Psychological, 29, 95-103.

Ortuño, V., \& Gamboa, V. (2008). Estudo Preliminar de Adaptação ao Português do Zimbardo Time Perspective Inventory - ZTPI, Actas da XIII Conferencia Internacional de Avaliação Psicológica: Formas e Contextos, Braga: Universidade do Minho.

Rammstedt, B., \& John, O. P. (2007). Measuring personality in one minute or less: A 10-item short version of the Big Five Inventory in English and German. Journal of Research in Personality, 41(1), 203-212.

Robins, R. W., Tracy, J. L., Trzesniewski, K., Potter, J., \& Gosling, S. D. (2001). Personality correlates of self-esteem. Journal of Research in Personality, 35(4), 463-482.

Zimbardo, P. G., Keough, K. A., \& Boyd, J. N. (1997). Present time perspective as a predictor of risky driving. Personality and Individual Differences, 23(6), 1007-1023.

Zimbardo, P. G., \& Boyd, J.N. (1999). Putting time perspective: A valid, reliable indivudualdifferences metric. Journal of Personality and Social Psychology, 77(6), 1271-1288. 